Volume 2, No. 1, 2020

P-ISSN: 2655-5166

E-ISSN: $2715-2103$

(0)

Homepage : http://journal.iaimsinjai.ac.id/indeks.php/retorika

\title{
STRATEGI KOMUNIKASI PADA PELAYANAN KESEHATAN MASYARAKAT UMUM (Study Kasus Rumah Sakit Sultan Dg. Radja Bulukumba)
}

\author{
Musliadi $^{1}$ \\ ${ }^{1}$ Institut Agama Islam Muhammadiyah Sinjai, \\ Jl.Sultan Hasanuddin, No. 20 Balangnipa, Sinjai \\ E-mail:adhyimus@gmail.com,Tlp:+085211917683
}

\begin{abstract}
Abstrak
Tujuan dari penelitian ini yaitu untuk mengetahui strategi komunikasi pada pelayanan kesehatan masyarakat umum di Rumah Sakit Sultan Dg. Radja Bulukumba serta untuk mengetahui hambatan-hambatan penerapan strategi komunikasi komunukasi terhadap pelayanan kesehatan masyarakat umum pada Rumah Sakit Sultan Dg Radja Bulukumba. Dalam penelitian ini, peneliti menggunakan jenis penelitian kualitatif. Adapun tipe penelitian ini bersifat deskriptif dengan menggunakan metode kualitatif. Kemudian pendekatan yang digunakan adalah studi kasus. Pendekatan tersebut dilakukan kepada orang-orang yang terkait dengan kegiatan pelayanan kesehatan masyarakat umum pada Rumah Sakit Sultan Dg. Radja Bulukumba. Metode pengumpulan data yang penulis gunakan dalam penelitian ini adalah dokumentasi, wawancara, dan observasi. Berdasarkan hasil penelitian dan Pembahasan dapat ditarik kesimpulan bahwa strategi komunikasi pelayanan kesehatan masyarakat umum pada Rumah Sakit Sultan Dg. Radja Bulukumba adalah mengenal khalayak dengan cara menganalisis kebutuhan khalayak, memahami dan mengerti keadaan khalayak serta memberikan masukan dengan menggunkan bahasa yang mudah dipahami oleh khayak. Kemudian penyusunan pesan yaitu melalui tahap pra interaksi guna mengetahui latar belakang pasien untuk mempermudah dalam proses penyampaian pesan. Sedangngkan penetapan metode pesan yang disampaikan oleh petugas, yaitu komunikasi verbal dan non verbal. Komunikasi verbal yaitu dorongan perawat kepada pasien dengan menggunakan bahasa lisan atau ucapan sedangkan komunikasi non verbal yaitu dorongan yang diberikan oleh perawat kepada pasien dengan menggunakan bahasa tubuh atau gerakan tubuh. Adapun hambatan-hambatan penerapan strategi komunukasi terhadap pelayanan kesehatan masyarakat umum pada rumah Sakit Sultan Dg Radja Bulukumba adalah adanya keterbatasan jumlah sumber daya manusia serta sarana dan prasarana.
\end{abstract}

Kata Kunci : Strategi Komunikasi, Pelayanan Kesehatan

\section{Pendahuluan}

Pelayanan publik merupakan salah satu bagian dari capaian sasaran pemerintah yang menghendaki terwujudnya masyarakat yang mandiri dan sejahtera. Peningkatan 
"Retorra RETORIKA

Jurmal Kajian Komunikasi dan Penyiaran Islam

Volume 2, No. 1, 2020

P-ISSN: 2655-5166

E-ISSN: $2715-2103$

(6) Homepage : http://journal.iaimsinjai.ac.id/indeks.php/retorika

layanan publik tidak hanya berupa pengurusan administrasi akan tetapi pelayanan dasar berupa kesehatan, pendidikan, lingkungan dan eknomi mikro merupakan bagian dari pelayanan publik yang tidak dapat dihindarkan dalam pemberian layanan (Ali Alamsyah Kusumadinata dan Maria Fitriah, 2017:226).

Susanto (2010: 114) mengemukakan jika pelayanan publik tak kunjung membaik maka good governance yang merupakan reformasi dari birokrasi akan sulit diwujudkan. Good governance diartikan sebagai kesepakatan yang menyangkut pengaturan negara yang diciptakan bersama oleh pemerintah, masyarakat madani dan sektor swasta demi terwujudnya kesejahteraan social. Upaya tersebut diperlukan suatu komunikasi yang efektif di mana komunikasi dinilai efektif bila rangsangan yang disampaikan dan dimaksudkan oleh pengirimnya ataupun sumber sejalan dengan rangsangan yang ditangkap dan dipahami oleh penerima pesan itu sendiri.

Strategi komunikasi yang baik adalah strategi yang dapat menetapkan atau menempatkan posisi seseorang secara tepat dalam komunikasi dengan lawan komunikasinya, sehingga dapat mencapai tujuan komunikasi yang telah ditetapkan. Keberadaan strategi komunikasi tidak terlepas dari adanya tujuan yang akan dicapai. Hal ini ditunjukkan oleh suatu jaringan kerja yang membimbing tindakan yang akan dilakukan, dan pada saat yang sama strategi akan mempengaruhi tindakan tersebut. Adapun prasyarat yang diperlukan untuk merumuskan strategi komunikasi dengan cara meningkatkan pemahaman tentang tujuan, artinya bila memahami tentang tujuan maka dengan mudah menentukan strategi untuk mencapai tujuan tersebut. Tanpa tujuan, maka tindakan yang dibuat

Komunikasi dalam profesi keperawatan merupakan faktor pendukung pelayanan keperawatan profesional yang dilaksanakan oleh perawat, dalam mengekspresikan peran dan fungsinya. Salah satu kompetensi perawat yang harus dimiliki adalah kemampuan berkomunikasi dengan efektif dan mudah dipahami dalam pelayanan keperawatan. Kemampuan berkomunikasi akan mendasari upaya pemecahan masalah pasien, mempermudah pemberian bantuan, baik dalam pelayanan medik, maupun psikologi. Berdasarkan hasil observasi awal penulis, diketahui bahwa 
"Retorra RETORIKA

Jurmal Kajian Komunikasi dan Penyiaran Islam

Volume 2, No. 1, 2020

P-ISSN: 2655-5166

E-ISSN: $2715-2103$

(9) Homepage : http://journal.iaimsinjai.ac.id/indeks.php/retorika

masih ada keluhan-keluhan seperti lambatnya proses administrasi rawat inap dan rawat jalan. Pelayanan rawat inap adalah pelayanan administrasi yang utama karena pelayanan ini mempunyai interaksi pasien antara rumah sakit berlangsung dalam waktu yang cukup lama. pelayanan administrasi yang diberikan oleh rumah sakit harus mendapatkan perhatian penuh ini merupakan hubungan yang sensitive menyangkut kepuasan pasien selama berada dirumah sakit.

Selama rawat inap pasien akan dilayani oleh tim medis dengan pelayanan pemeriksaaan dan asuahan perawatan. Sebelum pasien dibawa keruangan rawat inap terlebih dahulu melakukan administrasi lalu dibawa ke ruang rawat inap dan akhirnya pasien akan di perbolehkan keluar dari rumah sakit dan melakukan administrasi sebelum pasien pulang. Disinliah harapan pasien akan memperoleh pelayanan yang sebaik-baiknya dan pihak rumah sakit akan berusaha semaksimal mungkin dapat memberikan pelayanan sesuai dengan keinginan pasien.

Selain itu untuk mempermudah komunikasi antara pihak Rumah Sakit dengan masyarakat, bagian Hubungan Masyarakat (Humas) Rumah Sakit Sultan Dg. Radja Bulukumba telah memasang beberapa kotak pengaduan yang disediakan di hampir seluruh ruangan perawatan, seperti di ruang perawatan Asoka, Mawar, Melati, Flamboyan dan Seruni. Layanan tersebut merupakan tindak lanjut dari beberapa saran yang disampaikan oleh masyarakat kepada Humas Rumah Sakit Sultan Dg. Radja Bulukumba untuk menyediakan kontak pengaduan layanan dan informasi rumah sakit sebagai sarana informasi bagi masyarakat yang ingin mengetahui layanan apa saja yang diberikan oleh pihak rumah sakit.

Berdasarkan pada hasil penelitian sebelumya yang dilakukan oleh Anindya Pertiwi Hele dkk, (2018) dengan judul Peningkatan Pelayanan Berbasis Strategi Komunikasi Organisasi pada RSUD Luwu menunjukkan bahwa strategi komunikasi organisasi yang berkaitan dengan upaya pengulangan pesan yang disampaikan belum mendukung terjadinya komunikasi yang efektif, ini disebabkan pesan yang disampaikan secara lisan kurang jelas kepada bawahan sehingga butuh penyampaian ulang dan penyampaian informasi kembali, pemberian nama obat secara lisan 
"Retorra RETORIKA

Jurmal Kajian Komunikasi dan Penyiaran Islam,

Volume 2, No. 1, 2020

P-ISSN: 2655-5166

E-ISSN: $2715-2103$

(6) Homepage : http://journal.iaimsinjai.ac.id/indeks.php/retorika

sehingga salah di identifikasi oleh perawat, via telepon juga menimbulkan ketidakjelasan pesan serta tulisan dokter yang buruk yang terkadang menyulitkan tugas seorang perawat sehingga akan berdampak terhadap pola pelayanan. Kedua Penetapan waktu, strategi komunikasi organisasi yang berkaitan dengan penetapan waktu dalam penyampaian pesan masih belum optimal.

Selanjutnya adalah hasil Penelitian Ni Made Sumiyanti, (2016) dengan judul Strategi Komunikasi Perawat Dalam Meningkatkan Kepuasan Pasien di Instalasi Rawat Inap Rumah Sakit Umum Daerah Wangaya Kota Denpasar yang menunjukkan bahwa strategi komunikasi perawat yang digunakan perawat dalam meningkatkan kepuasan pasien adalah : strategi komunikasi interpersonal dan persuasif, sedangkan tingkat kepuasan pasien dapat diketahui sebagian besar pasien rawat inap merasa puas dalam menjalani perawatan di Instalasi Rawat Inap RSUD Wangaya Denpasar.

Terkait dengan strategi komunikasi oleh pihak Rumah Sakit Sultan Dg. Radja Bulukumba dalam memberikan pelayanan kesehatan kepada masyarakat tentunya diperlukan keahlian tersendiri oleh para komunikator dalam menyamapaikan pesan kepada masyarakat dengan tujuan untuk memastikan bahwa masyarakat mengerti dan paham dengan apa yang disampaikan selain itu sikap penerimaan masyarakat terhadap pesan yang diberikan dapat terus terjalin dengan baik guna mencapai tujuan yang hendak dicapai oleh pihak komunikator dari proses komunikasi tersebut. Berdasrkan urain tersebut di atas maka dalam penelitian ini penulis hendak mengkaji mengenai strategi komunikasi pada pelayanan kesehatan masyarakat umum (Study Kasus Rumah Sakit Sultan Dg. Radja Bulukumba)

\section{Metode}

Penelitian sebagai upaya untuk memoperoleh kebenaran, harus disadari oleh proses berpikir ilmiah yang dituangkan dalam metode ilmiah. (Noor Juliansyah 2001:22). Penentuan suatu metode yang digunakan dalam suatu penelitian akan menentukan bagaimana hasil dari keabsahan dan tingkat kebenaran hasil penelitian. Oleh karena itu dalam penelitian ini peneliti berusaha mengurai segala permasalahan mengenai strategi komunikasi pada pelayanan kesehatan masyarakat umum pada 
"Retorra RETORIKA

Jurmal Kajian Komunikasi dan Penyiaran Islam

Volume 2, No. 1, 2020

P-ISSN: 2655-5166

E-ISSN: $2715-2103$

(9) Homepage : http://journal.iaimsinjai.ac.id/indeks.php/retorika

Rumah Sakit Sultan Dg. Radja Bulukumba. Adapun waktu penelitian ini rencananya akan dilaksanakan selama 2 bulan pada tahun 2019. Sedangkan lokasi penelitian ini dilaksanakan di Rumah Sakit Sultan Dg. Radja Bulukumba.

Dalam penelitian ini, peneliti menggunakan jenis penelitian kualitatif. Metode penelitian secara umum diartikan sebagai suatu kegiatan ilmiah yang dilakukan secara bertahap dimulai dengan penentuan topik, pengumpulan data dan menganalisis data, sehingga nantinya diperoleh suatu pemahaman dan pengertian atas topik tertentu. Penelitian kualitatif adalah pengumpulan data pada suatu latar alamiah, dengan menggunakan metode alamiah, dan dilakukan oleh orang atau peneliti yang tertarik secara alamiah (Moleong, 2007:5).

Tipe penelitian ini bersifat deskriptif dengan menggunakan metode kualitatif. Kemudian pendekatan yang digunakan adalah studi kasus. Pendekatan tersebut dilakukan kepada orang-orang yang terkait dengan kegiatan pelayanan kesehatan masyarakat umum pada Rumah Sakit Sultan Dg. Radja Bulukumba.

Sumber data yang digunakan adalah data primer yakni data yang diperoleh secara langsung dari narasumber. Data primer berupa kata-kata dan tindakan-tindakan orang-orang yang diamati yang diperoleh melalui wawancara kepada informan yang berkaitan dengan strategi komunikasi pada pelayanan kesehatan masyarakat umum pada Rumah Sakit Sultan Dg. Radja Bulukumba. Selanjutnya Data yang diperoleh secara tidak langsung. Data tersebut berupa buku, literature, jurnal, laporan-laporan, surat kabar, hasil penelitian terdahulu dan dokumen-dokumen lain yang berkaitan dengan penelitian ini.

Informan dalam penelitian ini menggunakan teknik Purposive Sampling yakni dengan cara sengaja karena alasan-alasan sifat yang diketahui dari sampel tersebut atau menetapkan informan yang dianggap tahu dalam masalah yang sedang diteliti secara mendalam. Oleh karena itu, dalam penelitian ini jumlah informan yang ditentukan adalah Kepala Rumah Sakit Sultan Dg. Radja Bulukumba, Kapala Bagian Humas Rumah Sakit Sultan Dg. Radja Bulukumba, Pegawai/staf bagian pelayanan 
Returea RETORIKA

Jurmal Kajian Komunikasi dan Penyiaran Islam

Volume 2, No. 1, 2020

P-ISSN: 2655-5166

E-ISSN: 2715-2103

(용 Homepage : http://journal.iaimsinjai.ac.id/indeks.php/retorika

Rumah Sakit Sultan Dg. Radja Bulukumba dan Masyarakat penerima layanan kesehatan.

Metode pengumpulan data yang digunakan adalah Dokumentasi, Wawancara, dan Observasi. Sedangkan teknik analisa data yang digunakan yaitu kualitatif. Adapun langkah-langkah dalam menganalisis data dalam penelitian kualitatif adalah reduksi data (Data Reduction), penyajian data (Data Display), dan penarikan kesimpulan dan verifikasi

Keabsahan data dilakukan dengan menggunakan empat macam triangulasi untuk mencapai keabsahan :

a. Triangulasi data Menggunakan berbagai sumber data, seperti dokumen, arsip, hasil wawancara, hasil observasi atau juga dengan mewawancarai lebih dari satu subjek yag dianggap memiliki sudut pandang yang berbeda.

b. Triangulasi pengamat Adaya pengamat diluar peneliti yang turut memeriksa hasil pengumpulan data. Dalam penelitian ini, misalnya pembimbing bertindak sebagai pengamat (export judgement) yang memberikan masukan terhadap hasil pengumpulan data.

c. Triangulasi teori Penggunaan berbagai teori yang berlainan untuk memastikan bahwa data yang dikumpulkan sudah memenuhi syarat.

d. Triangulasi metode Penggunaan berbagai metode untuk meneliti suatu hal, seperti metode wawancara dan metode observasi.

\section{Hasil dan Pembahasan}

\subsection{Strategi komunikasi pada pelayanan kesehatan masyarakat umum pada}

\section{Rumah Sakit Sultan Dg. Radja Bulukumba}

Berdasarkan hasil penelitian pada Rumah Sakit Sultan Dg. Radja Bulukumba, dapat dijelaskan beberapa strategi komunikasi pada pelayanan kesehatan masyarakat umum sebagai berikut:

a. Mengenal Khalayak

Mengenal khalayak merupakan langkah pertama bagi petugas pelayanan kesehatan pada rumah Sultan Dg. Radja Bulukumba agar komunikasi yang dilakukan 
Retorea RETORIKA

Jurmal Kajian Komunikasi dan Penyiaran Islam

Volume 2, No. 1, 2020

P-ISSN: 2655-5166

E-ISSN: $2715-2103$

(6) Homepage : http://journal.iaimsinjai.ac.id/indeks.php/retorika

dapat diterima dengan baik oleh masyarakat. Sebagaimana telah dijelaskan bahwa proses komunikasi khalayak itu sama sekali tidak pasif melainkan aktif sehingga antara komunikator dan komunikan bukan saja terjadi hubungan melainkan juga terjadi proses saling berinteraksi artinya komunikan dapat menyampaikan pendapat secara terbuka oleh komunikator dan begitu juga sebaliknya. Dalam penyusunan strategi komunikasi pengenalan terhadap khalayak menjadi penting sebagai langkah awal untuk mempermudah komunikasi terhadap masyarakat khususnya dalam memberikan pelayanan.

Adapun cara yang dilakukan untuk dapat mengenal khalayak adalah dengan memberikan salam, senyum, memberikan keramahtamahan kepada pasien, dan menanyakan keluhan pasien. Setiap petugas pelayanan sebelum melakukan komunikasi harus mengenal sasaran yang hendak dituju. Sebagaimana pendapat dari Cangara, (2008:26) yang menjelaskan bahwa khalayak merupakan pihak yang menjadi sasaran pesan yang dikirim oleh komunikator. Hal ini tentu saja bergantung pada tujuan komunikasi, apakah agar komunikan hanya sekedar mengetahui (dengan metode informatif) atau agar komunikan melakukan tindakan tertentu (metode persuasif atau instruktif). Sasaran komunikasi petugas pelayanan ditentukan berdasarkan kondisi yang dihadapi oleh masyarakat. Dengan mengetahui kondisi yang dialami oleh masyarakat maka petugas dapat memberikan pelayanan sesuai dengan kehendak masyarakat atau pasien.

Petugas medis dalam sehari dapat bersinggungan dengan puluhan bahkan ratusan pasien. Tentunya sebagai manusia biasa, mereka tidak dapat mengingat satu persatu detail pasien yang ditangani. Ditambah pula dengan fakta bahwa pekerja medis bekerja dengan sistem shift. Perawat yang menangani di pagi hari akan berbeda dengan yang merawat di malam hari. Oleh sebab itu, peran aktif pasien sangat diperlukan untuk keselamatan pasien itu sendiri. Menanyakan nama dan tanggal lahir pasien adalah hal yang dilakukan petugas medis untuk memastikan bahwa pemeriksaan yang dilakukan, serta obat dan terapi lain yang 


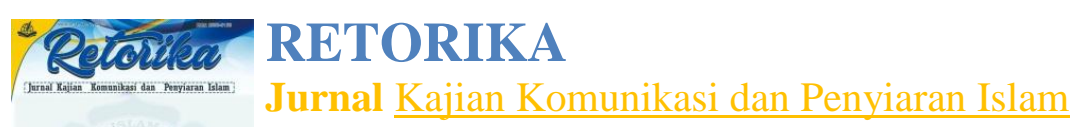

Volume 2, No. 1, 2020

P-ISSN: 2655-5166

E-ISSN: 2715-2103

(0)

Homepage : http://journal.iaimsinjai.ac.id/indeks.php/retorika

diberikan ditujukan kepada pasien yang tepat agar terhindar dari bahaya kesalahan medis yang disebabkan oleh kesalahan identifikasi.

Pengenalan terhadap khalayak atau pasien didukung oleh kemapuan sumberdaya manusia yang dimiliki oleh Rumah Sakit Sultan Dg. Radja Bulukumba. Berdasarkan data dokumen Rumah Sakit Sultan Dg. Radja Bulukumba bahwa pada umumnya petugas Rumah Sakit Sultan Dg. Radja Bulukumba memiliki tingkat pendidikan yang cukup memadai sebagaimana terlihat pada tabel 4.3 berikut:

Tabel 4.4

Distribusi Pegawai Negeri Sipil Berdasarkan Pangkat, Golongan, Jenis Kelamin dan Tingkat Pendidikan di RSUD H. Sulthan Daeng Radja Kabupaten Bulukumba Tahun 2019

\begin{tabular}{|c|c|c|c|c|c|c|c|c|c|c|c|}
\hline \multirow[t]{2}{*}{ NO } & \multirow{2}{*}{ PANGKAT/GOL } & \multicolumn{2}{|c|}{\begin{tabular}{|c|} 
JENIS \\
KELAMIN \\
\end{tabular}} & \multicolumn{7}{|c|}{ PENDIDIKAN } & \multirow[t]{2}{*}{ JML } \\
\hline & & $\mathrm{L}$ & $\mathrm{P}$ & S2 & S1 & D3 & D1 & SMA & SMP & SD & \\
\hline 1 & Pembina Utama / IV.e & 1 & 1 & & 2 & & & & & & 2 \\
\hline 2 & Pembina Utama Madya /IV.d & 2 & 4 & & 6 & & & & & & 6 \\
\hline 3 & Pembina Utama Muda/IV.c & 2 & 1 & 1 & 2 & & & & & & 3 \\
\hline 4 & Pembina TK.I / IV.b & 2 & 4 & 2 & 4 & & & & & & 6 \\
\hline 5 & Pembina / IV.a & 7 & 14 & 10 & 11 & & & & & & 21 \\
\hline & JUMLAH & 14 & 24 & 13 & 25 & & & & & & 38 \\
\hline 6 & Penata Tk.I / III.d & 10 & 22 & 8 & 13 & 8 & & 3 & & & 32 \\
\hline 7 & Penata / III.c & 10 & 17 & 9 & 14 & 4 & & & & & 27 \\
\hline 8 & Penata Muda Tk. I / III.b & 8 & 54 & 3 & 49 & 10 & & & & & 62 \\
\hline 9 & Penata Muda / III.a & 11 & 64 & & 46 & 29 & & & & & 75 \\
\hline & JUMLAH & 39 & 157 & 20 & 122 & 51 & 0 & 3 & & & 196 \\
\hline 10 & Pengatur Tk.I / II.d & 8 & 40 & & & 47 & & 1 & & & 48 \\
\hline 11 & Pengatur / II.c & 6 & 11 & & 9 & 3 & & 5 & & & 17 \\
\hline 12 & Pengatur Muda Tk. I/II.b & 3 & 3 & & & & & 6 & & & 6 \\
\hline 13 & Pengatur Muda / II.a & & 3 & & & & & 3 & & & 3 \\
\hline & JUMLAH & 17 & 57 & 0 & 9 & 50 & 0 & 15 & 0 & & 74 \\
\hline 14 & Juru Tk.I / I.d & 2 & & & & & & 2 & & & 2 \\
\hline 15 & Juru / I.c & 3 & & & & & & & 2 & 1 & 3 \\
\hline 16 & Juru Muda Tk.I / I.b & 2 & & & & & & & 1 & 1 & 2 \\
\hline 17 & Juru Muda / I.a & 2 & & & & & & & & 2 & 2 \\
\hline & Jumlah & 9 & 0 & & & & 0 & 2 & 3 & 4 & 9 \\
\hline & Jumlah Total & 79 & 238 & 33 & 156 & 101 & 0 & 20 & 3 & 4 & 317 \\
\hline
\end{tabular}

Sumber Data: Sub Bagian Umum dan Kepegawaian, 2019 
Retortea RETORIKA

Jurmal Kajian Komunikasi dan Penyiaran Islam

Volume 2, No. 1, 2020

P-ISSN: 2655-5166

E-ISSN: 2715-2103

(6) Homepage : http://journal.iaimsinjai.ac.id/indeks.php/retorika

Dari tabel tersebut di atas terlihat bahwa tingkat pendidikan pegawai SI sebanyak 238 orang, S2 Sebanyak 33 orang, D3 sebanyak 101 orang dan SMA sebanyak 20 orang, SMP 3 orang dan SD 4 orang. Dari keseluruhan pegawai maupun staff yang ada, dapat dikatakan bahwa kemampuan sumber daya manusia pegawai maupun staf cukup baik khsusnya dalam hal membangun komunikasi kepada pasien atau masyarakat dengan jumlah pendidikan S1sebanyak 231 orang.

Dari hasil wawancara, observasi dan dokumentasi dapat disimpulkan bahwa strategi komunikasi pelayanan oleh petugas Rumah Sakit Sultan Dg. Radja Bulukumba dalam mengenal khalayak telah dilakukan dengan baik. Setiap petugas berusaha mengenal khalayak dengan cara mempelajari atau membaca riwayat pasien, serta menanyakan nama dan tanggal lahir dengan tujuan adalah agar dapat mengenali pasien serta menghindari terjadinya kesalahan pada saat pemberian obat demi keselamatan pasien.

b. Menyusun Pesan

Setelah memahami permasalahan situasi khalayak, langkah selanjutnya adalah menyusun pesan. Pesan yang disampaikan harus disesuaikan dengan kondisi komunikan atau khalayak sebagai sasaran komunikasi. Khalayak disini ialah masyarakat Kabupaten Bulukumba yang mendapatkan pelayanan dari pihak Rumah Sakit Sultan Dg. Radja Bulukumba. Dalam menyusun pesan para petugas pelayanan menentukan pesan-pesan yang terkait dengan hal-hal yang berkaitan dengan pelayanan di Rumah Sakit Sultan Dg. Radja Bulukumba.

Penyusunan pesan oleh petugas pemberi pelayanan pada Rumah Sakit Sultan Dg. Radja Bulukumba harus memperhatikan kebutuhan pasien serta penggunaan bahasa yang mudah dimengerti serta menentukan ide pokok permasalahn yang hendak disampaikan kepada pasien. Penyampaian pesan petugas dapat berlangsung efektif apabila memperhatikan beberapa faktor seperti keadaan psikologi pasien yang akan diajak berkomunikasi. Apabila keadaan pasien sedang dalam keadaan labil, maka tentu saja petugas atau perawat akan kesulitan dalam berkomunikasi dengan pasien. 
Retortea RETORIKA

Jurmal Kajian Komunikasi dan Penyiaran Islam

Volume 2, No. 1, 2020

P-ISSN: 2655-5166

E-ISSN: 2715-2103

(6) Homepage : http://journal.iaimsinjai.ac.id/indeks.php/retorika

Dari uraian tersebut di atas dapat disimpulkan bahwa penyusunan pesan oleh petugas pelayanan pada Rumah Sakit Sultan Dg. Radja Bulukumba yaitu melalui tahap Pra interaksi yakni petugas atau perawat harus mengetahui latar belakang pasien untuk mempermudah dalam proses penyampaian pesan kemudian menetapkan tindakan yang harus dilakukan kepada pasien. Selanjutnya petugas atau perawat memperkenalkan diri serta mendorong pasien mengungkapkan perasaan dan pikirannya setelah itu petugas memberikan pesan terkait dengan berbagai hal yang harus dilakukan ataupun hal yang tidak boleh dilakukan selama proses perawatan. Tujuan penyusunan pesan tersebut dimaksudkan untuk memudahkan pasien dalam menerima pesan yang disampaikan sebagaimana pendapat Hardiyansyah, (2015:70) bahwa komunikasi yang efektif yaitu ketika pesan yang ingin disampaikan oleh komunikator dapat diterima dan diartikan oleh khalayak dalam bentuk yang persis sama seperti yang diinginkan dan dimaksudkan oleh komunikator tersebut.

c. Menetapkan Metode

Setelah proses pengenalan khalayak dan penyusunan pesan maka strategi komunikasi selanjutnya adalah menetapkan metode penyampaian pesan agar pesan yang disampaikan menarik perhatian komunikan. Dalam menetapkan metode tersebut sedikitnya ada dua metode penyampaian pesan yang digunakan pada Rumah Sakit Sultan Dg. Radja Bulukumba yaitu pesan secara verbal dan pesan secara non verbal.

Pesan verbal Adalah sebuah proses komunikasi, dimana pada komunikasi verbal simbol atau pesan verbal adalah semua jenis symbol yang menggunakan satu kata atau lebih. Hampir semua rangsangan wicara yang kita sadari termasuk kedalam kategori pesan verbal yang disengaja. Yaitu usaha yang dilakukan secara sadar untuk berhubungan dengan orang lain secara lisan. Sedangkan pesan non verbal adalah semua isyarat yang bukan kata-kata. Istilah non verbal biasanya digunakan untuk melukiskan semua peristiwa komunikasi diluar kata-kata yang terucap dan tertulis. Pada saat yang sama kita harus menyadari bahwa banyak peristiwa dan perilaku nonverbal ini ditafsirkan melalui simbol-simbol verbal. 
Retortea RETORIKA

Jurmal Kajian Komunikasi dan Penyiaran Islam

Volume 2, No. 1, 2020

P-ISSN: 2655-5166

E-ISSN: $2715-2103$

(6) Homepage : http://journal.iaimsinjai.ac.id/indeks.php/retorika

Metode penyampaian pesan dengan menggunakan pesan verbal atau secara lisan ini dianggap baik, karena dengan pesan verbal ini perawat bisa secara details memberikan penjelasan mengenai pesan tersebut kepada pasien. Akan tertapi hal tersebut kurang efektif jika dalam konteks penyampaian pesan yang dilakukan oleh perawat kepada pasien yang mengalami gangguan berupa pendengaran, karena keterbatasan pasien dalam menerima sebuah pesan tidak bisa langsung dicerna oleh pasien. Efektivitas penyampaian pesan ini tergantung tingkat kemampuan pasien dalam menangkap atau menerima pesan yang disampaikan.

Banyak bentuk dari pesan verbal yang diberikan perawat kepada pasien, bentuk pesan verbal yang sering disampaikan perawat biasanya seperti ajakan kepada pasien untuk melakukan sesuatu dan memberi keterangan mengenai kegunaan dan keuntungan dari kegiatan tersebut. Contoh lain dari pesan verbal yang diberikan perawat kepada pasien seperti ketika seorang perawat akan mulai melakukan proses pemeriksaan mengenai perkembangan kesehatan pasien, sebelum melakukan pemeriksaan tersebut seorang perawat harus memberikan pesan berupa informasi mengenai biodata perawat, tujuan perawat datang menemui pasien, menentukan kontrak waktu dengan pasien. Semua itu adalah bentuk pesan verbal yang sering diberikan perawat kepada pasien.

Dalam komunikasi perawat dengan pasien kejelasan mengenai isi pesan sangat diperhatikan saat komunikasi berlangsung. Dalam penyampaian pesannya perawat tidak boleh berbelit-belit atau bertele-tele karena pasien akan sulit menerima pesan tersebut, maka dari itu pesan yang perawat sampaikan kepada pasien harus singkat, padat dan jelas serta menggunakan bahasa yang mudah dimengerti oleh pasien.

Komunikasi yang baik akan mampu mengarahkan terjadinya komunikasi yang lebih akrab antara satu individu atau kelompok terhadap individu atau kelompok lain. Komunikasi yang baik pula dapat meminimalisir kecurigaan-kecurigaan yang terjadi dalam hubungan perawat dengan pasien. Komunikasi dapat dikatakan sebagai komunikasi yang efektif dalam merubah sikap, pandangan perilaku. Keefektifan komunikasi adalah karena komunikator dapat menguasai komunikasi yang sedang 
"Retorra RETORIKA

Jurmal Kajian Komunikasi dan Penyiaran Islam

Volume 2, No. 1, 2020

P-ISSN: 2655-5166

E-ISSN: $2715-2103$

(6) Homepage : http://journal.iaimsinjai.ac.id/indeks.php/retorika

berlangsung misalnya komunikasi secara tatap muka. Komunikasi tatap muka digunakan apabila komunikator mengharapkan perubahan tingkah laku dari komunikan. Seorang perawat seyogyanya dapat memfasilitasi kondisi munculnya keterbukaan. Kondisi keterbukaan dapat diwujudkan bila perawat maupun pasien dapat berinteraksi secara jujur terhadap stimulus yang datang. Terjadinya komunikasi secara tatap muka antara perawat dengan pasien. Perlu diciptakan suasana dialogis antara perawat dengan pasein. Keterbukaan mengisyaratkan perawat bersedia menerima kritik-kritik dan saran yang disampaikan pasien.

Dari uraian di atas maka dapat disimpulkan bahwa penetapan metode pesan yang disampaikan oleh petugas pelayanan di Rumah Sakit Sultan Dg. Radja Bulukumba dibagi menjadi dua, yaitu komunikasi verbal dan non verbal. Komunikasi verbal yaitu dorongan perawat kepada pasien dengan menggunakan bahasa lisan atau ucapan sedangkan komunikasi non verbal yaitu dorongan yang diberikan oleh perawat kepada pasien dengan menggunakan bahasa tubuh atau gerakan tubuh. Adapun kedua metode penyampaian pesan tersebut digunakan berdasarkan kondisi pasien. Masing-masing metode penyampaian pesan digunakan dengan tujuan agar pesan yang disampaikan dapat diterima dengan baik oleh pasien.

1. Hambatan-hambatan penerapan strategi komunukasi terhadap pelayanan kesehatan masyarakat umum pada Rumah Sakit Sultan Dg. Radja Bulukumba

Berdasarkan hasil penelitian pada Rumah Sakit Sultan Dg. Radja Bulukumba, dapat dijelaskan beberapa hambatan-hambatan penerapan strategi komunukasi sebagai berikut:

a) Keterbatasan Sumber daya manusia

Keterbatasan sumber daya manusia merupakan salah satu faktor penghambat dalam penerapan strategi komunikasi terhadap pelayanan kesehatan masyarakat umum pada Rumah Sakit Sultan Dg. Radja Bulukumba karena untuk menunjang kelancaran komunikasi tersebut diperlukan tenaga atau sumber daya manusia yang memadai sehingga petugas atau perawat memiliki cukup waktu untuk 
Volume 2, No. 1, 2020

P-ISSN: 2655-5166

E-ISSN: $2715-2103$

Homepage : http://journal.iaimsinjai.ac.id/indeks.php/retorika

berkomunikasi dengan pasien. Namun dengan terbatasnya jumlah pegawai menyebabkan komunikasi petugas menjadi kurang efektif

Tebatasnya sumber daya manusia yang dimiliki oleh Rumah Sakit Sultan Dg. Radja Bulukumba merupakan penghambat bagi petugas untuk melakukan komunikasi karena tidak sebanding dengan banyaknya jenis pelayanan yang harus diselesaikan. Adapun jenis pelayanan yang diberikan pada Rumah Sakit Sultan Dg. Radja Bulukumba adalah sebagai berikut:

Tabel 4.5 Distribusi Jenis Pelayanan di RSUD Sultan Daeng Radja Bulukumba Tahun 2016

\begin{tabular}{|l|l|c|c|}
\hline No. & \multicolumn{1}{|c|}{ Pelayanan } & Ada & Tidak Ada \\
\hline A. & Pelayanan Medik Umum & & \\
\hline 1 & Pelayanan medik dasar & $\sqrt{ }$ & \\
\hline 2 & Pelayanan medik gigi mulut & $\sqrt{ }$ & \\
\hline 3 & Pelayanan KIA/KB & & \\
\hline B. & Pelayanan Gawat Darurat & $\sqrt{ }$ & \\
\hline 1 & 24 Jam \& 7 hari seminggu & & \\
\hline C. & Pelayanan Medik Dasar & $\sqrt{ }$ & \\
\hline 1 & Penyakit Dalam & $\sqrt{ }$ & \\
\hline 2 & Kesehatan Anak & $\sqrt{ }$ & \\
\hline 3 & Bedah & & \\
\hline 4 & Obstetri \& Ginekologi & $\sqrt{ }$ & \\
\hline D. & Pelayanan Spesialis Penunjang Medik & $\sqrt{ }$ & \\
\hline 1 & Radiologi & $\sqrt{ }$ & \\
\hline 2 & Patologi Klinik & $\sqrt{ }$ & \\
\hline 3 & Anestesiologi & $\sqrt{ }$ & \\
\hline 4 & Rehabilitasi Medik & $\sqrt{ }$ & \\
\hline 5 & Patologi Anatomi & & \\
\hline E. & Pelayanan Medik Spesialis lain & & \\
\hline 1 & Mata & & \\
\hline 2 & Telinga Hidup Tenggorokan & & \\
\hline 3 & Syaraf & & \\
\hline 4 & Jantung dan Pembuluh Darah & & \\
\hline 5 & Kulit dan Kelamin & & \\
\hline 6 & Kedokteran Jiwa & & \\
\hline
\end{tabular}


Volume 2, No. 1, 2020

P-ISSN: 2655-5166

E-ISSN: 2715-2103

Homepage : http://journal.iaimsinjai.ac.id/indeks.php/retorika

\begin{tabular}{|l|l|c|c|}
\hline 7 & Paru & $\sqrt{ }$ & \\
\hline 8 & Orthopedi & & $\sqrt{ }$ \\
\hline 9 & Urologi & & $\sqrt{ }$ \\
\hline 10 & Bedah Syaraf & & $\sqrt{ }$ \\
\hline 11 & Bedah Plastik & & $\sqrt{ }$ \\
\hline 12 & Kedokteran Forensik & & \\
\hline F. & Pelayanan Medik Spesialis Gigi Mulut & & $\sqrt{ }$ \\
\hline 1 & Bedah Mulut & & $\sqrt{ }$ \\
\hline 2 & Konservasi/Endodonsi & & $\sqrt{ }$ \\
\hline 3 & Orthodonti & & \\
\hline G. & Pelayanan Medik Subspesialis & $\sqrt{ }$ & \\
\hline 1 & Bedah & & $\sqrt{ }$ \\
\hline 2 & Penyakit Dalam & & $\sqrt{ }$ \\
\hline 3 & Kesehatan Anak & & $\checkmark$ \\
\hline 4 & Obstetri \& Ginekologi & & \\
\hline H. & Pelayanan Keperawatan dan Kebidanan & $\sqrt{ }$ & \\
\hline 1 & Asuhan Keperawatan & $\sqrt{ }$ & \\
\hline 2 & Asuhan Kebidanan & $\sqrt{ }$ & \\
\hline I. & Pelayanan Penunjang Klinik & $\sqrt{ }$ & \\
\hline 1 & Perawatan Intensif & $\sqrt{ }$ & \\
\hline 2 & Pelayanan Darah & $\sqrt{ }$ & \\
\hline 3 & Gizi & $\sqrt{ }$ & \\
\hline 4 & Farmasi & $\sqrt{ }$ & \\
\hline 5 & Radiologi & & \\
\hline 6 & Sterilisasi Instrumen & & \\
\hline 7 & Rekam Medik & & \\
\hline J. & Pelayanan penunjang non klinik & & \\
\hline 1 & Laundry/linen & & \\
\hline 2 & Jasa Boga/Dapur & & \\
\hline 3 & Teknik dan Pemeliharaan Fasilitas & & \\
\hline 4 & Pengelolaan Limbah & & \\
\hline 5 & Gudang & & \\
\hline 6 & Ambulance & & \\
\hline 7 & Komunikasi & & \\
\hline 8 & Kamar Jenazah & & \\
\hline 9 & Pemadam Kebakaran & & \\
\hline 10 & Pengelolaan Gas Medik & & \\
\hline & & & \\
\hline
\end{tabular}


Volume 2, No. 1, 2020

P-ISSN: 2655-5166

E-ISSN: 2715-2103

(8)

Homepage : http://journal.iaimsinjai.ac.id/indeks.php/retorika

\begin{tabular}{|l|l|}
11 & Penampungan Air Bersih
\end{tabular}

Sumber Data: Seksi Pelayanan Medik, 2019.

\begin{tabular}{|c|c|}
$\sqrt{ }$ & \\
$41(79 \%)$ & $11(21 \%)$ \\
\hline
\end{tabular}

Berdasarkan data dokumen tersebut di atas dapat dijelaskan bahwa terdapat 52 jenis pelayanan yang telah ditetapkan pada Rumah Sakit Sultan Dg. Radja Bulukumba dan sebanyak 41 atau sebesar $79 \%$ diataranya sudah tersedia dan 11 atau sebanyak $21 \%$. Sementara dari segi jumlah sumber daya manusia yang ada pada Rumah Sakit Sultan Dg. Radja Bulukumba sebagaimana data dokumen yang penulis dapatkan adalah sebanyak 40 orang sebagaimana terlihat pada tabel berikut:

Tabel 4.6 Distribusi Tenaga Medis di RSUD H. Andi Sulthan Daeng Radja Kabupaten Bulukumba Tahun 2019

\begin{tabular}{|c|c|c|c|c|c|c|c|}
\hline \multirow{2}{*}{ No } & \multirow{2}{*}{ Jenis Tenaga } & \multirow{2}{*}{$\begin{array}{c}\text { Standar } \\
\text { kebutuhan } \\
\text { Minimal } \\
\text { Tenaga } \\
\text { RS Kelas B }\end{array}$} & \multirow{2}{*}{$\begin{array}{c}\text { Jumlah } \\
\text { SDM } \\
\text { Yang } \\
\text { Ada }\end{array}$} & \multicolumn{4}{|c|}{ Status Ketenagaan } \\
\hline & & & & $\frac{0}{Z}$ & $\underbrace{a}$ & 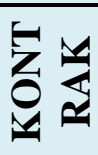 & $E$ \\
\hline $\mathbf{A}$ & $\begin{array}{l}\text { TENAGA MEDIK UMUM } \\
\text { DAN SPESIALIS DASAR }\end{array}$ & & & & & & \\
\hline 1 & Dokter Umum & 12 & 12 & 10 & 0 & 2 & 0 \\
\hline 2 & Dokter Gigi & 3 & 3 & 3 & 0 & 0 & 0 \\
\hline 3 & Dokter Ahli Bedah Umum & 3 & 2 & 2 & 0 & 0 & 0 \\
\hline 4 & Dokter Ahli Penyakit Dalam & 3 & 3 & 3 & 0 & 0 & 0 \\
\hline 5 & Dokter Ahli Anak & 3 & 2 & 1 & 0 & 1 & 0 \\
\hline 6 & $\begin{array}{lll}\text { Dokter Ahli } & \text { Obstetrik \& } \\
\text { Ginekologi } & & \\
\end{array}$ & 3 & 2 & 2 & 0 & 0 & 0 \\
\hline B & $\begin{array}{lr}\text { TENAGA } & \text { MEDIK } \\
\text { SPESIALIS PENUNJANG }\end{array}$ & & & & & & \\
\hline 1 & Dokter Ahli Anastesi & 2 & 2 & 2 & 0 & 0 & 0 \\
\hline 2 & Dokter Ahli Radiologi & 2 & 1 & 1 & 0 & 0 & 0 \\
\hline 3 & $\begin{array}{l}\text { Dokter Ahli } \quad \text { Rehabilitasi } \\
\text { Medik }\end{array}$ & 2 & 0 & 0 & 0 & 0 & 0 \\
\hline
\end{tabular}


Retorka RETORIKA

Jurmall Kajian Komunikasi dan Penyiaran Islam

Volume 2, No. 1, 2020

P-ISSN: 2655-5166

E-ISSN: 2715-2103

Homepage : http://journal.iaimsinjai.ac.id/indeks.php/retorika

\begin{tabular}{|c|c|c|c|c|c|c|c|}
\hline 4 & Dokter Ahli Patologi Klinik & 2 & 2 & 2 & 0 & 0 & 0 \\
\hline 5 & Dokter Ahli Patologi Anatomi & 2 & 1 & 0 & 0 & 1 & 0 \\
\hline $\mathbf{C}$ & $\begin{array}{l}\text { TENAGA MEDIK } \\
\text { SPESIALIS LAINNYA }\end{array}$ & & & & & & \\
\hline 1 & Dokter Ahli Bedah Orthopaedi & 0 & 0 & 0 & 0 & 0 & 0 \\
\hline 2 & Dokter Ahli Bedah Plastik & 0 & 0 & 0 & 0 & 0 & 0 \\
\hline 3 & Dokter Ahli Bedah Saraf & 0 & 0 & 0 & 0 & 0 & 0 \\
\hline 4 & Dokter Ahli Forensik & 0 & 0 & 0 & 0 & 0 & 0 \\
\hline 5 & Dokter Ahli Jiwa & 1 & 2 & 1 & 0 & 1 & 0 \\
\hline 6 & Dokter Ahli Kulit \& Kelamin & 1 & 1 & 1 & 0 & 0 & 0 \\
\hline 7 & Dokter Ahli Mata & 1 & 3 & 3 & 0 & 0 & 0 \\
\hline 8 & $\begin{array}{l}\text { Dokter Ahli Penyakit Jantung } \\
\text { \& PD }\end{array}$ & 1 & 1 & 0 & 0 & 1 & 0 \\
\hline 9 & Dokter Ahli Penyakit Paru & 1 & 1 & 0 & 0 & 1 & $\overline{0}$ \\
\hline 10 & Dokter Ahli Saraf & 1 & 1 & 1 & 0 & 0 & 0 \\
\hline 11 & Dokter Ahli THT & 1 & 1 & 1 & 0 & 0 & 0 \\
\hline 12 & Dokter Ahli Urologi & 0 & 0 & 0 & 0 & 0 & 0 \\
\hline $\mathbf{D}$ & \begin{tabular}{lrr} 
TENAGA & \multicolumn{2}{r}{ MEDIK } \\
SPESIALIS & GIGI \\
MULUT & &
\end{tabular} & & & & & & \\
\hline 1 & Dokter Gigi Ahli Bedah Mulut & 1 & 0 & 0 & 0 & 0 & 0 \\
\hline 2 & Dokter Gigi Ahli Gigi Anak & 0 & 0 & 0 & 0 & 0 & 0 \\
\hline 3 & $\begin{array}{l}\text { Dokter Gigi Ahli Konservasi } \\
\text { Gigi }\end{array}$ & 1 & 0 & 0 & 0 & 0 & 0 \\
\hline 4 & Dokter Gigi Ahli Ortodentik & 0 & 0 & 0 & 0 & 0 & 0 \\
\hline 5 & Dokter Gigi Ahli Prostodonsia & 0 & 0 & 0 & 0 & 0 & 0 \\
\hline 6 & Dokter Gigi Ahli Peny. Mulut & 0 & 0 & 0 & 0 & 0 & 0 \\
\hline 7 & Dokter Gigi Ahli Periodonsi & 0 & 0 & 0 & 0 & 0 & 0 \\
\hline \multicolumn{2}{|c|}{ Total } & 46 & 40 & 33 & $\mathbf{0}$ & 7 & $\mathbf{0}$ \\
\hline
\end{tabular}

Sumber Data: Seksi Pelayanan Medik, 2019.

Dari data tersebut di atas dapat dijelaskan bahwa Standar kebutuhan Minimal Tenaga medis sebanyak 46 orang sementara pada Rumah Sakit Sultan Dg. Radja Bulukumba jumlah sumberdaya manusia yang ada sebanyak 40 orang. 
"Retorra RETORIKA

Jurmal Kajian Komunikasi dan Penyiaran Islam

Volume 2, No. 1, 2020

P-ISSN: 2655-5166

E-ISSN: $2715-2103$

(2) Homepage : http://journal.iaimsinjai.ac.id/indeks.php/retorika

Ini menunjukkan bahwa Rumah Sakit Sultan Dg. Radja Bulukumba masih memiliki kekurangan jumlah sumber daya manusia.

Banyaknya jenis pelayanan yang disediakan di Rumah Sakit Sultan Dg. Radja Bulukumba terkadang menyebabkan pelayanan menjadi kurang maksimal. Hal tersebut disebabkan karena terbatasnya jumlah petugas pelayanan khusunya tenaga medis yang bertugas dalam memberikan pelayanan langsung kepada masyarakat.

Keterbatasan sumber daya manusia pada Rumah Sakit Sultan Dg. Radja Bulukumba merupakan salah satu faktor penghambat dalam menerapkan komunikasi kepada pasien. Hal tersebut disebabkan karena jumlah jenis pelayanan lebih banyak dibandingkan dengan jumlah tenaga medis yang tersedia. Terdapat 52 jenis pelayanan yang ada pada Rumah Sakit Sultan Dg. Radja Bulukumba sementara jumlah tenaga medis yang ada hanya 40 orang.

b) Keterbatasan sarana dan prasarana

Menurut Wursanto (2005) bahwa hambatan yang bersifat teknis teknis adalah hambatan yang disebabkan kurangnya sarana dan prasarana yang diperlukan dalam proses komunikasi. Dalam rangka menunjang kelancaran kerja dan komunikasi, pada rumah sakit Rumah Sakit Sultan Dg. Radja Bulukumba harus ditunjang dengan sarana dan prasarana atau fasilitas yang memadai seperti ketersediaan ruangan atau gedung yang cukup untuk menampung semua pasien. Keberadaan ruangan yang cukup tentunya akan sangat membantu kelancaran komunikasi namun sebaliknya jika ruangan yang tersedia kurang memadai maka sangat memungkinkan bagi perawat untuk dapat berkomunikasi dengan baik.

Keterbatasan jumlah ruangan merupakan faktor penghambat antara petugas dengan pasien. Hal tersebut disebabkan karena dengan banyaknya jumlah pasien akan membuat kondisi ruangan menjadi sempit ditambah lagi dengan jumlah pengunjung dari masing-pasien. Adapun jumlah ruangan yang tersedia pada Rumah Sakit Sultan Dg. Radja Bulukumba dapat dilihat pada tabel berikut: 
"Retorka RETORIKA

Jurmal Kajian Komunikasi dan Penyiaran Islam

Volume 2, No. 1, 2020

P-ISSN: 2655-5166

E-ISSN: 2715-2103

(6)

Homepage : http://journal.iaimsinjai.ac.id/indeks.php/retorika

Tabel 4.7.

Distribusi Fasilitas Kamar dan Tempat Tidur di Rumah Sakit Sulhan Daeng

Radja Kabupaten Bulukumba Tahun 2016

\begin{tabular}{|c|c|c|}
\hline No. & Ruang Rawat & Jumlah TT \\
\hline 1 & Pavilliun & 8 \\
\hline 2 & Perawatan Anak (Mawar) & 16 \\
\hline 3 & Perawatan Bedah (Melati) & 14 \\
\hline 4 & Perawatan Interna (Flamboyan) & 18 \\
\hline 5 & Perawatan Kelas III (Seruni) & 43 \\
\hline 6 & Perawatan Isolasi (Boungenville) & 8 \\
\hline 8 & Perawatan ICU & 4 \\
\hline 9 & Perawatan Perinatologi & 25 \\
\hline 10 & Instalasi Rawat Darurat & 7 \\
\hline 11 & Kamar Bersalin & 26 \\
\hline 12 & $\mathrm{CVCU}$ & 6 \\
\hline \multicolumn{2}{|r|}{ otal } & 175 \\
\hline
\end{tabular}

Sumber Data: Sub Bagian Rekam Medis \& Pelaporan, 2019

Berdasarkan table tersebut di atas bahwa jumlah ruangan yang tersedia pada Rumah Sakit Sultan Dg. Radja Bulukumba adalah sebanyak 175 rungan. Dari total jumlah ruangan yang ada masih terdapat beberapa ruangan yang dianggap masih kurang seperti ruangan perawatan Interna (Flamboyan) dan perawatan kelas III (Seruni). Selain hal tersebut di atas sebagaimana data yang penulis dapatkan di Rumah Sakit Sultan Dg. Radja Bulukumba juga ditemukan beberapa fasilitas penunjang yang masih dianggap kurang seperti thermometer, troli medikasi gunting hacting dan beberpa perlatan lainnya seperti yang tampak pada table berikut:

Tabel 4.8 Peralatan Keperawatan

\begin{tabular}{|l|l|c|c|c|c|}
\hline No & Nama Alat & Ada & Standar & Baik & Kekurangan \\
\hline 1 & Alat GV & & & & \\
& a. Pinset Anatomi & 18 & 18 & 18 & 0 \\
& b. Pinset Cerurgis & 18 & 18 & 18 & 0 \\
\hline
\end{tabular}


"Retortea RETORIKA

Jurmal Kajian Komunikasi dan Penyiaran Islam

Volume 2, No. 1, 2020

P-ISSN: 2655-5166

E-ISSN: 2715-2103

Homepage : http://journal.iaimsinjai.ac.id/indeks.php/retorika

\begin{tabular}{|l|l|c|c|c|c|}
\hline & c. Gunting Lurus & 12 & 12 & 12 & 0 \\
& d. Koomp & 12 & 12 & 12 & 0 \\
& e. Gunting Hecting & 2 & 6 & 2 & 4 \\
& f. Gunting kasa & 6 & 6 & 6 & 0 \\
& g. Arteri klem & 12 & 12 & 12 & 0 \\
\hline 2 & Tromol & 3 & 3 & 3 & 0 \\
\hline 3 & Korentang & 2 & 3 & 2 & 1 \\
\hline 4 & Tensi meter & 4 & 4 & 3 & 1 \\
\hline 5 & Tempat Korentang & 2 & 3 & 2 & 1 \\
\hline 6 & Termometer & 1 & 3 & 1 & 2 \\
\hline 7 & Troli medikasi & 1 & 3 & 1 & 2 \\
\hline 8 & Troli verbed & 1 & 1 & 1 & 0 \\
\hline 9 & Tiang infus & 39 & 39 & 39 & 0 \\
\hline 10 & Troli EKG & 1 & 1 & 1 & 0 \\
\hline 11 & Alat EKG & 2 & 2 & 2 & 0 \\
\hline 12 & Timbangan & 4 & 4 & 4 & 0 \\
\hline 13 & Tabung oksigen & 12 & 12 & 12 & 0 \\
\hline 14 & Mano meter & 5 & 8 & 5 & 3 \\
\hline 15 & Senter & 5 & 5 & 5 & 0 \\
\hline 16 & Tabung Pemadam & 6 & 6 & 6 & 0 \\
\hline
\end{tabular}

Berdasarkan data yang didapat, sebagian besar peralatan yang diperlukan sudah tersedia sesuai standar yang ditentukan di bangsal, meskipun ada beberapa alat yang masih kurang jumlahnya dan juga mengalami kerusakan. Selanjutnya dari hasil wawancara mengenai hambatan-hambatan penerapan strategi komunukasi terhadap pelayanan kesehatan masyarakat umum pada rumah Sakit Sultan Dg. Radja Bulukumba berkaitan dengan dengan mengenal khalayak, penyusunan pesan dan menetapkan metode dapat diuraikan sebagai berikut:

\section{Simpulan}

Berdasarkan hasil penelitian dan Pembahasan dapat ditarik kesimpulan sebagai berikut: Pertama, strategi komunikasi pelayanan kesehatan masyarakat umum pada Rumah Sakit Sultan Dg. Radja Bulukumba adalah mengenal khalayak dengan cara menganalisis kebutuhan khalayak, memahami dan mengerti keadaan khalayak serta memberikan masukan dengan menggunkan bahasa yang mudah dipahami oleh khayak. Kemudian penyusunan pesan yaitu melalui tahap pra interaksi guna 
"Retorra RETORIKA

Jurmal Kajian Komunikasi dan Penyiaran Islam

Volume 2, No. 1, 2020

P-ISSN: 2655-5166

E-ISSN: 2715-2103

(2)

Homepage : http://journal.iaimsinjai.ac.id/indeks.php/retorika

mengetahui latar belakang pasien untuk mempermudah dalam proses penyampaian pesan. Sedangngkan penetapan metode pesan yang disampaikan oleh petugas, yaitu komunikasi verbal dan non verbal. Komunikasi verbal yaitu dorongan perawat kepada pasien dengan menggunakan bahasa lisan atau ucapan sedangkan komunikasi non verbal yaitu dorongan yang diberikan oleh perawat kepada pasien dengan menggunakan bahasa tubuh atau gerakan tubuh. Kedua, hambatan-hambatan penerapan strategi komunukasi terhadap pelayanan kesehatan masyarakat umum pada rumah Sakit Sultan Dg Radja Bulukumba adalah adanya keterbatasan jumlah sumber daya manusia serta sarana dan prasarana.

\section{Daftar Pustaka}

Abidin, Yusuf Zainal. (2015). Manajemen Komunikasi: Filosofi, Konsep dan Aplikasi. Bandung: Pustaka.

Anny Isfandyarie. (2006). Tanggung Jawab dan Sanksi Bagi Dokter. Jakarta: Prestasi Pustaka.

Anwar Arifin. (1984). Strategi Komunikasi Suatu Pengantar Ringkas. Bandung: Armico.

Cangara, Hafied. (2014). Perencanaan dan Strategi Komunikasi. Jakarta : PT Raja Grafindo Persada.

Effendy, Onong Uchjana. (2005). Komunikasi : Teori dan Praktek. Bandung: Remaja Rosdakarya.

Emi, Mimin. (2004). Etika Keperawatan Aplikasi Pada Praktik. Jakarta: Kedokteran EGC: Jakarta.

Gulo, W. (2007). Metodologi Penelitian. Jakarta : Grasindo.

Hadiati Harmien, Koeswadji. (1998). Hukum Kedokteran di Dunia Internasional, Makalah Simposium. Jakarta: Medical Law.

Isfandyarie Anny. (2006). Tanggung Jawab Hukum dan Sanksi Bagi Dokter Buku I. Jakarta: Prestasi Pustaka.

Liliweri, Alo. (2001). Gatra-gatra Komunikasi Antar Budaya. Bandung: Remaja Rosdakarya.

Moleong, Lexy J. (2007). Metodologi Penelitian Kualitatif. Bandung: PT Remaja Rosdakarya. 
Volume 2, No. 1, 2020

P-ISSN: 2655-5166

E-ISSN: $2715-2103$

(2)

Homepage : http://journal.iaimsinjai.ac.id/indeks.php/retorika

Mulyana, Deddy. (2005). Ilmu Komunikasi : Suatu Pengantar. Bandung: Remaja Rosdakarya.

Noor, Juliansyah. (2011). Metodologi Penelitian: Skripsi, Tesis, Desertasi, dan Karya Ilmiah. Jakarta: Kencana.

Praptianingsih Sri. (2007). Kedudukan Hukum Keperawatan dalam Upaya Pelayanan Kesehatan di Rumah Sakit. Jakarta: PT. Raja Grafindo Persada.

Purwandi Atik. (2005). Konsep Kebidanan Sejarah \& Profesionalisme. Kedokteran Jakarta: EGC.

Sugiyono. (2009). Metode Penelitian Kuantitatif, Kualitatif dan R\&D. Bandung: Alfabeta.

Susanto, E.H. (2010). Kelambanan Reformasi Birokrasi dan Pola Komunikasi Lembaga Pemerintah. Jurnal Komunikasi ASPIKOM.

Tubb, S. L, dan Moss, S. (2006). Human Communication. Bandung: Remaja Rosdakarya.

Yusuf Zainal Abidin. (2015). Manajemen Komunikasi (Filosofi, Konsep, dan Aplikasi). Bandung: Pustaka Setia.

Veronica Komalawati. (2010). Peranan Informed Consent Dalam Transaksi Terapeutik (Persetujuan Dalam Hubungan Dokter dan Pasien). Bandung: PT. Citra Aditya Bakti.

Ali Alamsyah Kusumadinata dan Maria Fitriah. (2017). Strategi Komunikasi Pelayanan Publik Melalui Program Pos Pemberdayaan Keluarga. Jurnal Aspikom, Volume 3 Nomor 2, Januari.

Anindya Pertiwi Hele. (2018). "Peningkatan Pelayanan Berbasis Strategi Komunikasi Organisasi pada RSUD Luwu" Jurnal Komunikasi Profesional eISSN: 2579-9371, Vol 2, No 1, Juni.

Dede Wahyudi. (2013). Strategi Komunikasi Perwakilan Bkkbn Provinsi Kalimantan Timur Dalam Mensosialisasikan Piirogram KB. E-Journal Ilmu Komunikasi.

Ni Made Sumiyanti. (2016). "Strategi Komunikasi Perawat Dalam Meningkatkan Kepuasan Pasien di Instalasi Rawat Inap Rumah Sakit Umum Daerah Wangaya Kota Denpasar” Jurnal Kajian Ilmu Komunikasi, Vol 12 No 1.

Metodologi-Penelitian, $\quad$ https://docplayer.info/31238974-Bab-iii-metodologipenelitian.html diakses pada tanggal 19 september 2019 pukul 12.00 WIB.

Metode Penelitian, http://eprints.ums.ac.id/50490/6/BAB\%20III.pdf diakses pada tanggal 19 september 2019 pukul $12.00 \mathrm{WIB}$.

Komunikasi Kesehatan, https://pakarkomunikasi.com/komunikasi-kesehatan diakses pada tanggal 19 september 2019 pukul 12.00 WIB. 
Volume 2, No. 1, 2020

P-ISSN: 2655-5166

E-ISSN: $2715-2103$

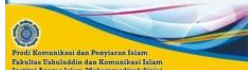

Homepage : http://journal.iaimsinjai.ac.id/indeks.php/retorika

Hambatan-Hambatan Komunikasi, https://pakarkomunikasi.com/hambatanhambatan-komunikasi diakses pada tanggal 19 september 2019 pukul 12.00 WIB.

Undang-Undang No. 29 Tahun 2004 tentang Praktik Kedokteran diakses pada tanggal 19 september 2019 pukul 12.00 WIB.

Undang-Undang Nomor 36 Tahun 2009 tentang Kesehatan diakses pada tanggal 19 September 2019 pukul 12.00 WIB. 